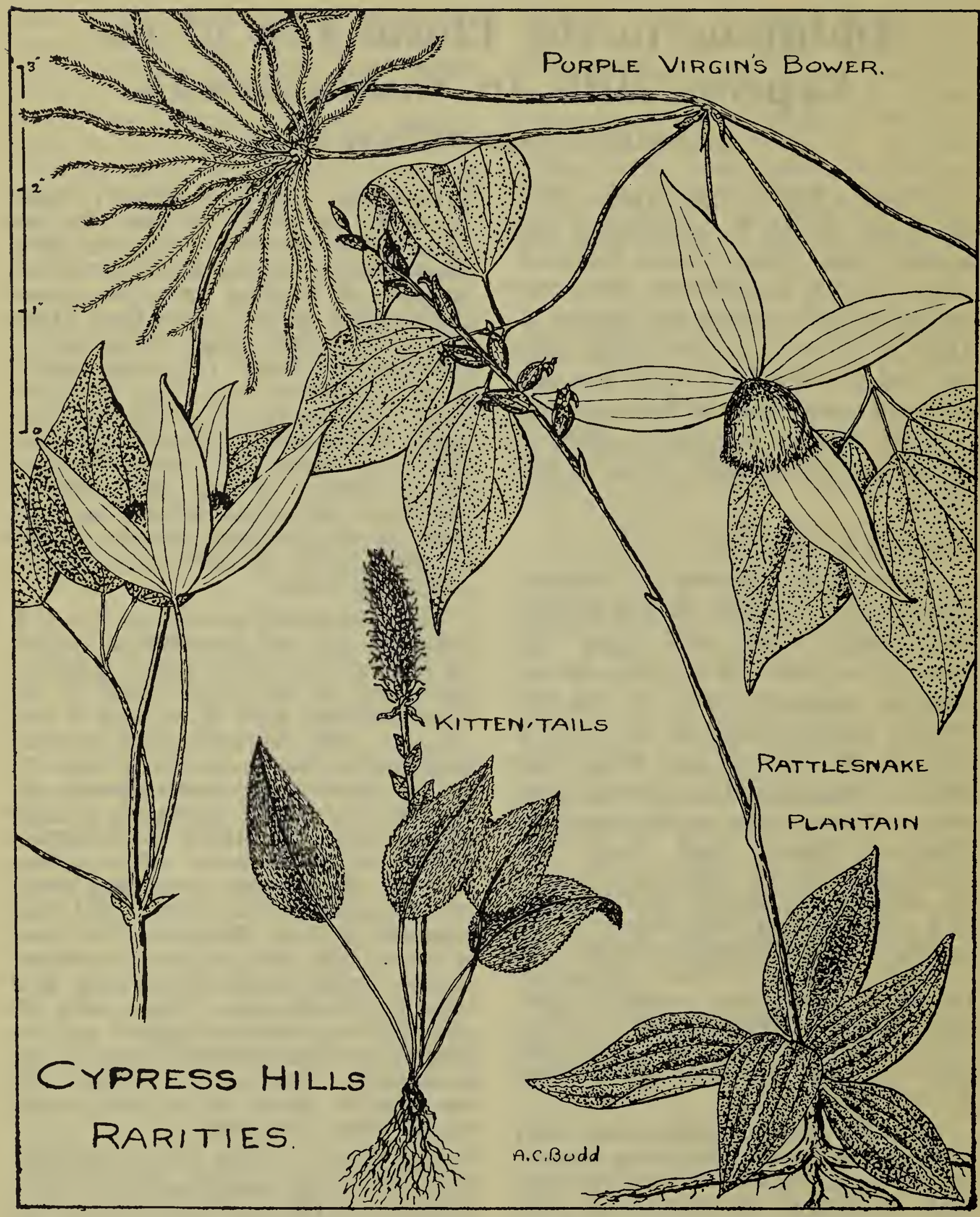

\title{
Some Cypress Hills Floral Rarities
}

ARCHIE BUDD, Swift Current, Sask.

In view of the suggestion that next year's summer meeting be in the Cypress Hills, probably Saskatchewan's outstanding botanical area, a few articles on exceptional plants of that district may not be out of place. There are at least twenty plants found in the Cypress Hills which are not reported else- where in the Province and this short series of articles will deal with some of these.

Shaded areas in the pine woods are the locations where we find the Rattlesnake Plantain, Goodyera decipiens (Hook.) Hubbard, an orchid, not a plantain, easily distinguished by its basal rosette of fleshy, dark 
green leaves, generally of a pinkish tinge below, and bearing a whitish line down the mid-rib above or mottled with white. The greenishwhite flowers are borne on a scape from 8 to 15 inches high and are about five sixteenths of an inch in length. This orchid is plentiful in the mountains and foothills region and also ranges right across the continent, but apparently its only location in Saskatchewan is our Cypress Hills. Other scientific names for this species are Goodyera oblongifolia Raf., Goodyera Menziesii Lindl. and Paramium decipiens Piper.

Climbing and trailing over trees and underbrush in the pine and poplar woodlands the Purple "Virgin's Bower is frequently found. Its rather untidy looking stems are shreddy barked and it bears opposite leaves, divided into three leaflets with stalks. The large, pale blue flowers are very showy, being from two to four inches across, with no petals but four, or occasionally five, petal-like sepals. The centre is a golden mass of stamens, staminodia or sterile stamens and thread-like styles, which after fertilization develop into fruit, each bearing a long hairy style and forming a dense globular grayish head. These plants climb by means of their leaf stalks. This climber is found through the Rockies and foothills regions and the dry intermountain region east of the Cascades, but the Cypress Hills appears to be its only location in Saskatchewan. Scientifically it is termed Clematis columbiana (Nutt) Torr. \& Gray, but has also been listed as Atragene columbiana Nutt. and as Clematis verticillaris DC. var. columbiana A. Gray, being by Asa Gray considered a variety of that eastern species.

The third plant in the sketch is a member of the Scrophulariaceae or the Snapdragon family, and is the Kitten-tails, Besseya wyomingensis (A. Nels.) Rydb. or Besseya rubra (Dougl.) Rydb. or Synthyris wyomingensis (A. Nels.) Raf. or even Wulfenia rubra Greene. "In a multitude of counsellors there is much wisdom" in spite of the fact that "too many cooks spoil the broth," so choose which name you like the best. This montane and foothills plant is by no means common in the Cypress Hills but may be found on the fescue prairie bench of the West Block. Its spike of fuzzy inflorescence and fruit give it the common name; the small purplish flowers have no petals but each has two protruding stamens. The flowering scapes are from four to twelve inches high with small, stalkless stem leaves, and several long-stalked basal leaves, generally reddish tinged. The West Block of the Cypress Hills appears to be our only Saskatchewan locality for this interesting plant.

It is to be hoped that this series of articles on our Cypress Hills unique flora will not lead to the despoiling of the plants but rather to a pride in the preservation of these species and their retention in our native vegetation. We, as nature lovers and students, should lead in the protection of our floral treasures especially in these days when vandalism seems so prevalent in most of the National Parks, both in Canada and the U.S.A.

\section{Familiar Wild Flowers}

By B. De Vries, Fort Qu'Appelle

\section{No. 3 ROSES}

Roses are one of our most beloved summer flowers. The large showy flowers make a colorful display along our country roads and woodland borders. Roses are cosmopolitan, seed-bearing plants whose species are difficult to distinguish.

The flower axis expands into an urn-shaped receptacle which in time becomes fleshy and encloses in its cavity the numerous fruit carpels.
From the edge of this urn or "hip" arise the five sepals and five petals and the numerous stamens. The hairy carpels, each containing one seed, are hidden within the "hip" which becomes fleshy and brightly coloured. These fruits remain attached to the bushes and add much to the beauty of our autumn and winter scenery, providing food for our winter birds. 